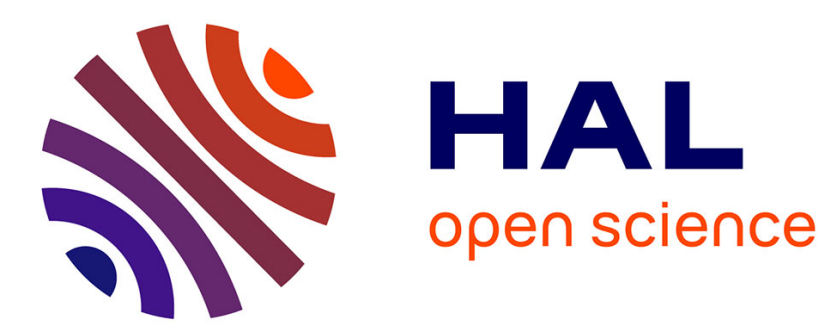

\title{
Study of the Peculiarities of Export Developments in EU Member Countries and in Armenia Karen Grigoryan
}

\section{To cite this version:}

Karen Grigoryan. Study of the Peculiarities of Export Developments in EU Member Countries and in Armenia. Romanian Journal of European Affairs, 2012, 12 (3), pp.65-82. 10.2139/ssrn.2142370 . hal-03581922

\section{HAL Id: hal-03581922 \\ https://hal.science/hal-03581922}

Submitted on 20 Feb 2022

HAL is a multi-disciplinary open access archive for the deposit and dissemination of scientific research documents, whether they are published or not. The documents may come from teaching and research institutions in France or abroad, or from public or private research centers.
L'archive ouverte pluridisciplinaire HAL, est destinée au dépôt et à la diffusion de documents scientifiques de niveau recherche, publiés ou non, émanant des établissements d'enseignement et de recherche français ou étrangers, des laboratoires publics ou privés. 


\title{
Study of the Peculiarities of Export Developments in EU Member Countries and in Armenia
}

\author{
Karen Grigoryan*
}

\begin{abstract}
This paper aims at investigating the role of integration and trade in the economic development of EU member countries and Armenia, which is one of the six countries of EU Eastern Partnership project. Building on the studies of comparative advantages and peculiarities of the inter and intra - trade of the various countries, the paper provides a general description of export developments and other related factors affecting economic developments in EU member countries, as well as Armenia during the last two decades, especially before and after the world financial-economic crisis. Special attention is paid to both - developed and developing EU member states. This study theoretically and empirically examines various problems in the export structure of the countries and key elements of export development strategy recommended.
\end{abstract}

Keywords: European integration, comparative advantages, inter and intra-trade, export, EU developed and developing countries, EU Eastern Partnership, Armenia

JEL classification: E23, E61, F17, F20, F43

Introduction: The role of integration and trade in the economic development of EU and Armenia

The mix of goods that a country produces and exports has important implications for economic growth (Hausmann et al., 2005). This phenomenon concerns the economic development of each country, as well as the European Union (EU). As it is known, the EU started out with six countries of equal development (France, Germany, Belgium, Italy, Luxembourg, and the Netherlands), but included countries with lower levels of development in the subsequent years.

Definitely, the main advantages of joining the EU are the following: EU membership helps to increase the possibility of specialized production. EU's population provides a bigger market, than the biggest developed country in the world - the United States. It can achieve economies of scale, especially for the products with complicated structure such as computer, legal drugs, nuclear reactor, jet liner and modern weapons. This kind of economy induces production to operate more effectively on the international market.

\footnotetext{
* Karen Grigoryan, PhD in Economics, is Associate Professor at the Department of Macroeconomics, Armenian State University of Economics, Yerevan. He is former Head of Department of Educational Reforms and International Relations of Armenian State University of Economics (ASUE). Also beneficiary of Erasmus Mundus program for scholars, funded by European Union, and Fulbright Scholar Program, funded by US Department of State, and Research Scholarship, funded by German Academic Exchange Service (DAAD) and Open Society Institute (OSI). E-mail: kgrigoryanh@mail.ru Acknowledgements: The author would like to express his gratefulness to Professor Doctor Diana Antonova (Head of Department of Management and Business Development, University of Ruse, Bulgaria) for her generous support, discussions and recommendations that substantially improved this paper.
} 
Consequently, a larger, more intense competition can produce higher efficiency. In the EU free trade means more effective distribution and usage of production factors. And finally, the EU countries enjoy economies of scale and the increasing competition can produce a faster growth rate. It is also possible that the EU growth forecasts in their turn cause growth.

As a result, the integration process in the EU has had a liberalizing effect on the flows of goods and productive factors between participating economies. Integration involves an intensification of economic relationships, particularly trade relationships, in those countries which have decided to reduce or eliminate trade barriers.

Furthermore, European integration has changed the comparative advantages of countries and highlighted the role of national institutions and capabilities in location decisions (Barrell and Pain, 1999). The removal of internal barriers to trade and capital mobility during the single market programme (SMP) has been accompanied by a rapid growth in multinational activity in the EU both by European and non-European firms (Barrell and Pain, 1997, 1998), stimulating research in the policies available to national governments to affect location decisions and the potential benefits of inward investment. In addition, various production factors have a different degree of mobility: for instance land with 0 degree and capital with very high degree of mobility. In general, at the international level economic resources are less mobile than at the national level (Mkrtchyan, 2007).

As it is known, the integration process and free trade policy are interrelated. In order to evaluate free trade agreements and, more generally trade liberalization, one can rely on one of the following frameworks:

- $\quad$ the traditional neoclassical framework, which emphasizes differences between countries stemming from differences in factor endowments or technologies;

- $\quad$ new trade theory models, which emphasize trade between similar countries motivated by scale economies and preference for variety.

Consequently, the last one has been extended to allow productivity differences across firms. Additionally, this allows identifying three different channels through which trade liberalization can affect one of the key macroeconomic issue - unemployment: specialization, changes in productivity, and mobility. Remarkably, these three channels can work in opposite directions and their relative importance depends on the type of trade - intra-industry trade and inter-industry trade, and also the skill-class of a worker.

In fact, the gains from trade are distributed very unequally. When a skilled worker abundant country opens to trade with a country that is unskilled worker abundant, the biggest loses are suffered by the skilled workers in the import sector in the skill abundant country. However, average unemployment among skilled workers goes down, while average unemployment among unskilled workers goes up.

The current account balance is one of the most frequent statistically significant indicators in explaining crisis incidence. Export performance as measured by export market shares diverged across EU Member States. Some Member States benefited from a surge in exports of goods and services while others recorded a rather low export performance. To some extent, this disparity reflects differences in geographical specialisation, with some Member States being better positioned in fast growing export destinations such as East Asia and Eastern Europe. The causes of this divergence in export market shares can be related to both differences in trade openness and in product composition of exports (Cuerpo et al., 
2012). Similar arguments refer to the product composition of export clusters. In addition, technology-intensive products and services are found to be much less sensitive to changes in relative costs than low-technology sectors. Overall, relative prices only partly explain export performance, while other factors such as product quality and market structure can play an important role (Carlin et al., 2001). It should be noted that increase in demand and asset bubbles tend to amplify domestic price and wage growth, which translates into real effective appreciation and reduces the competitiveness of domestic tradable products in international markets and at home (e.g., Berger and Nitsch, 2010; Biroli et al., 2010; Zemanek et al., 2010). Weakening trade competitiveness eliminates the ability of countries with big deficits to earn export revenues and to service the accumulated foreign debt.

The financial crisis has had a pervasive impact on the real economy of the EU, but some EU countries have been more vulnerable than others, reflecting inter alia differences in current account positions, exposure to real estate bubbles or the presence of a large financial centre. The trade squeeze was deeper than might be expected on the basis of historical relationships, possible due to the composition of the demand shock (mostly affecting trade intensive capital goods and consumer durables), the unavailability of trade finance and a faster impact of activity on trade as a result of globalization and the prevalence of global supply chains (European Economy 7, 2009).

In fact, Armenia is a member of EU Eastern Partnership project and the export development is now mainly oriented to European experience and markets. Trade, particularly the export sector, plays a significant role in the economic development of Armenia, since the domestic market is very small and the production capacity of the country is significantly bigger.

Now, the largest export markets for Armenia are EU and Commonwealth of Independent States (CIS) member countries. More than half of the goods exported from Armenia are directed towards EU countries, and about 1/3 of it to CIS countries. But the export structure of Armenia has several weaknesses that need to be addressed in order to develop the export sector.

The following sections in this paper lay out the main features of the export developments, as well as other related factors affected economic developments respectively in the developed and developing countries - members of the EU and Armenia, as well. The conclusions draw out lessons and recommendations for export developments.

\section{Export development and other factors affecting the economic growth of the developed countries of the EU}

Certainly, the experience of many countries showed that export revenues play an important role in achieving economic growth in both low- and high-income countries. Exports are crucial for the economic development of nations (Almeida Couto et al. 2006; Girma et al. 2004; Lages and Montgomery 2004). However, there are some characteristic peculiarities and differences among them.

Specifically, in developing countries, the export promotion is mostly considered an instrument of economic development, whereas in the developed countries, the focus on export promotion programs is one of strengthening the competitiveness of companies. 
However, the promotion policy in developing countries also seeks this goal (Grigoryan, 2006).

Indeed, the economy of scale plays a significant role in all countries, including developed countries. It should be distinguished between two sets of reasons for contagion effects in the spatial growth process, both depending on economies of scale.

Accordingly, internal economies of scale at the level of the firms have become increasingly important. As they evolve with technology the number of locations used may change.

At the same time, external economies between firms due to proximity can also reduce costs, determining locations to become cumulatively more attractive. These might include the local availability of skilled labour or scientific knowledge as well as direct links with other firms (Venables, 1996). The size of the local market also matters, as it is easier for agglomerations to develop with bigger markets.

Remarkably, a number of calibrated models suggest that the single market programme (SMP) in Europe should also have significant effects on location (Ottaviano and Puga, 1997). Initial declines in the costs of market entry stimulate agglomeration, with industries exploiting economies of scale and locating close to large markets.

Hence, there are agglomeration effects, since the four largest EU economies (Germany, UK, France, and Italy) are the four most important hosts. It is also apparent that the share of world-wide production undertaken in Europe has risen during the last two decades. Germany is the dominant production location, suggesting that even for tradable goods in a Europe with few barriers to trade; location decisions do not just reject relative labour costs. However, operations in the UK, and also in Italy, are relatively labour intensive.

Moreover, based on economic and geographic data ${ }^{1}$, Denmark, Finland, Portugal, the Netherlands, Sweden and France reveal comparative advantages in natural resources intensive industries. Especially Portugal but also Italy and Greece present advantages in labour intensive industries. Finland, Sweden, the Netherlands, UK, Italy and Austria are net exporters in products of capital-intensive industries. Finally, during the last decade, the most outstanding net-exporters in human capital intensive industries are Ireland, Germany, the Netherlands and France (Frias, Iglesias and Neira, 1999).

In fact, Ireland, Spain and UK did not exploit their advantages in this field as they could; meanwhile, Italy was extremely competitive in spite of its much lower advantage. Only Germany, Ireland, the Netherlands and France make an intensive utilization of their human capital endowment in their industrial foreign trade. However, some other countries such as the United Kingdom, Sweden, Denmark or Finland have also privileged positions in this respect that have not been until now fully exploited. The feeble status of Greece, Portugal, Spain and Italy is also maintained by their lower educational figures and comparatively low percentage of GDP that they assign to Research and Development (R\&D) expenditure.

In general, the net exporters of capital are mostly those countries that are exporters of capital (human or physical) intensive products: Germany, the Netherlands, the UK and Finland. On the contrary, Belgium, Spain and Portugal, which are importers of products

\footnotetext{
${ }^{1}$ Source: Organisation for Economic Co-operation and Development (OECD), Statistics portal, http://stats.oecd.org/ index.aspx
} 
intensive in capital, have received large flows of direct investment (Frias, Iglesias and Neira, 1999).

Germany was severely hit by the slump in world trade in the wake of the global financial crisis. Based upon expansionary fiscal and monetary policy and higher exports, the German economy rebounded in mid-2009, but the recovery temporarily lost momentum again around the turn of 2009/10. Germany, though, appears well placed to benefit from the pick-up in world trade, notably in emerging markets. However, weaker demand from some of its traditional trading partners and still fragile financing conditions could weigh on the strength of the recovery.

France was relatively less affected by the crisis than its neighbours. This was mainly due to the importance of economic stabilizers, the recovery plan and the social policy framework, combined with a relatively low degree of openness of the economy and limited size of the manufacturing sector, in particular compared to Germany. The French economy came out of the recession in the second quarter of 2009 thanks both to a rebound in exports and to a better domestic consumption as the recovery plan was underway. The structure analysis of French exports clearly points to the medium-high technology positioning of French products, which, together with relatively low investment in R\&D and underperformances in the education system places the country in a situation of innovation follower in some products. The large share of low-medium technology intensity products exposes France to competition from both industrialized and emerging economies. Consequently, France's share of exports of goods in world trade decreased on average more than that of its main trading partners (Germany, Italy, Spain, UK). In France, since 2000, the current account balance is on a deteriorating trend which implies that net exports have been hampering growth. Improving notably non-price competitiveness will be the key to boosting growth so that the French economy relies less heavily on domestic sources (Occasional paper 65, European Commission, 2010).

The UK's revealed competitive advantage for goods in the intermediate range of the technology and R\&D intensity spectrum could be built on by extending the strong science and technology base. Finally, as part of a wider comprehensive skills and education strategy, efforts to raise skill levels in the manufacturing sector would help address lacking competitiveness in the goods export spectrum.

In Italy, a breakdown of exports by product category reveals a relative predominance of labour-intensive products and low-technology goods. Such an export mix competes with, rather than being complementary to, that of the emerging economies, making Italy more exposed than other euro-area countries to increasing global competition. As a partial response to these competitive pressures, a restructuring process has been taking place in the tradable sector in the recent years, whereby Italy's exports moved up the quality ladder, while maintaining their specialization in labour-intensive sectors.

In Finland, a relatively concentrated industry structure and highly specialized exports renders the economy vulnerable to sector-specific shifts.

While the crisis and rising unemployment has led to wage moderation in Denmark, this is also the case for many countries. It is therefore questionable whether wage moderation in Denmark will be enough to restore the economy's global competitiveness. Danish exports have traditionally been less sensitive to the business cycle due to its high content of pharmaceuticals, agricultural products and "green technology" products, which also 
helped cushion the fall in exports as global trade collapsed during the crisis. However, the Danish export product mix and the loss of competitiveness experienced during the last decade suggest that exporters may not be able to reap the full benefit of the global recovery in trade.

Sweden's very export dependent economy was severely affected by the financial crisis. Its trade-openness, however, implies sluggish demand from its trading partners and this continues to affect the strength of the recovery.

Belgium has been hit hard by the global crisis: the fall in world trade had a strong impact on the country's small open economy. Belgian exports are mainly oriented towards other euro area countries, whose import growth has been considerably lower than world trade growth in recent years, and they show a specialization in medium-technology goods that are easy to imitate, such as chemicals and steel. In addition, relatively high unit labour costs have a negative impact on exports; these are prompted by strong increases in wages, notably as a consequence of the wage bargaining system and its outcome. Export growth would be supported by facilitating technological upgrading and specialization in products and services with a higher technological content through focusing on key sectors such as biotechnology and health care.

In Netherlands since exports dropped less sharply than world trade in 2009, partly due to the composition of Dutch exports, and given the continuous gain in market share over the past years, the Netherlands is in a good position to profit from the revival of world trade.

Being highly concentrated on machines, vehicles and processed materials, Austrian exports were particularly hard hit by the global downturn.

Spain is a relatively closed economy, so there is a larger share of resources in sectors other than the export sector. In this context, the Spanish economy needs to boost competitiveness in the economy, notably in the non-tradable sector, and enhance export oriented activities.

Greece's current difficulties are rooted in the accumulation of vulnerabilities over the past decade. Growth was high, but based on unsustainable drivers and it went together with significant losses in external competitiveness and increases in macro imbalances. The patterns of sector and geographical trade specialization show that Greece not only exports too little, but its exports of goods are mainly concentrated in low-technology and slow-growing demand products (Occasional paper 65, European Commission, 2010).

However, the evolution of inter-industrial trade does not confirm the expectations of a deeper specialization, for instance, in the north of Europe in human capital-intensive industries and in labour-intensive industries in the south. In addition, the development of intra-industrial trade does not suggest intensification in the exploitation of scale economies in the south.

Nevertheless, despite comparative advantages in labour-intensive production, southern regions in Europe must be aware of the superiority of developing countries in this respect which will be eventually revealed in the long term. At a certain point in time, the mentioned reason will make it necessary for them to specialize in physical and human capital intensive industries incurring very high costs of adjustment. So, it is highly desirable that southern regions make an effort to accumulate physical and human capital in spite of its relatively high costs. 
For this reason, regional and national policies in the EU should be addressed to improve infrastructures (transport, communications, public services etc.), overcome differences in educational levels and impulse the efforts in R\&D made by the institutions and enterprises of the least-favoured regions.

Definitely, trade among developed countries differs significantly from trade with the developing countries. Since developed countries are relatively similar, in the sense that they use similar production technologies and have similar characteristics of the production factors, they produce similar products. Trade between them therefore mainly takes the form of intra-industry trade, which refers to a situation in which countries export and import goods belonging to the same sector. France will, for instance, export Renaults to Germany and Germany will export BMW to France. On the contrary, trade among developed and developing countries takes the form of inter-industry trade: countries export goods belonging to one sector and import goods belonging to another sector. Germany would, for instance, export Volkswagens to Malaysia and import rubber in exchange (Jansen, 2000).

Furthermore, empirical research has tried to disentangle horizontal from vertical intraindustry trade in countries' trade flows. Greenaway, Hine and Milner (1994) find that at the end of the eighties two-thirds of UK's intra-industry trade was vertical. Fontagné, Freudenberg and Péridy (1997) found that more than half of the total intra-EU trade was vertical intra-industry trade in 1994. Several studies indicate that countries specialise in certain quality niches. Jansen and Landesmann (1999) find that the quality a country tends to export depends positively on its level of development, as it is correlated with per capita GDP. This explains why the European Union belongs to the high quality exporters when compared to other countries and regions. But it also explains why within the European Union the "richer", northern countries tend to export higher quality products than the "poorer", southern countries (Jansen, 2000).

Consequently, the largest part of EU trade is intra-industry trade, as this is the type of trade that prevails among developed countries, which are EU's major trading partners. Even trade with developing and transition economies has become increasingly intraindustry. Besides, there is evidence that within intra-industry trade, trade in vertically differentiated goods is more important than trade in horizontally differentiated goods. This evidence is interesting in the light of the fact that most theories that link trade with skill inequalities are based on models of inter-industry trade.

\section{Export development and other factors affecting the economic growth of developing countries of EU}

Generally, the structure of comparative advantages of EU new members - Central and Eastern European countries (CEECs) - in spite of decades of capital intensive development, still points at their relatively cheap and abundant labour. Thus, according to the traditional international trade theory a conclusion of asymmetric inter-industry trade pattern may be drawn: trade of labour-intensive goods for capital- and technology-intensive goods (e.g. discussion in Czarny and Lang, 2002). The new trade theory (e.g. Krugman, 1998; Amiti, 1998; Ottaviano, 2011) concentrating on intra-industry trade indicates low vertical intra- 
industry trade (between lower and higher quality goods in the same sector) as likely to occur between developed and developing countries in the EU. Both trends are financially unfavourable and they create sensitivity and dependence on stronger trading partners (Lissowska, 2002).

In fact, the most advanced is Hungary, being classified among EU new members mostly in technology intensive industries (power generating machines, plastics, telecommunication and video equipment, office machinery and computers). The two other countries exhibit strong export position in labour intensive industries (for Poland: paper and paperboard, clothing, for the Czech Republic: textile) and in capital intensive industries in majority dating back to the pre-transition period (iron and steel for both, nonferrous metals for Poland, road vehicles for the Czech Republic).

More specifically, Hungary is fitting thanks to a relatively strong position as an exporter of telecommunication and office equipment. Specialisation of other countries' export does not match this pattern except possibly road vehicles in the Czech Republic, the export of which is carried out in Poland as well. Therefore, nowadays those three countries seem kept outside the mainstream competition game, except for Hungary in some selected areas $^{2}$.

Actually, during the last decade the degree of intra-industry trade stays the highest for the Czech Republic followed by Hungary and Poland. In all three countries, slow vertical trade prevails and horizontal trade (goods of similar quality) strengthens. Unlike the other two, Hungary has a substantial degree of high vertical trade (exchange of higher for lower quality goods). Accordingly, in the Czech Republic and Poland expanding export of road vehicles coincides with a shift from low to horizontal trade in this industry. The other intensively exporting industries in those two countries (machinery in the Czech Republic, non-ferrous metals and clothing in Poland, iron and steel in both) reveal a low vertical trade pattern. As to Hungary, some highly exporting industries (like machinery) are predominantly of low vertical trade while others (telecommunication equipment) increase their horizontal trade (Lissowska, 2002).

In Hungary, due to a sudden decline in external demand and high uncertainty regarding the severity and duration of the crisis, both exports and industrial production dropped significantly in 2009. Hungary is the second most open economy in the EU 27. In terms of export structure, the country has a comparative advantage in research-intensive products, making exports more sensitive to the business cycle.

Importantly, the relationship between the size of export together with its technological level, measured by intra-industry trade type index, and the role of FDI in the same industry is of interest. Theoretical opinions on this relationship are diverse and depend on motivation and strategy of investment. It is generally considered that demand-oriented projects usually substitute export from the home country. On the contrary, foreign direct investments (FDI) seeking resources or aiming at supply rationalisation through horizontal concentration in bigger plants or looking for vertical specialization, all imply growth of both import and export.

\footnotetext{
2 Source: External and intra-European Union trade, data 2004-2009, 2010 edition, Eurostat, European Commission, website http://ec.europa.eu/eurostat
} 
Hence, based on data of foreign affiliates' sales in net industry, sales as a measure of FDI engagement (e.g. Hunya, 2001), a relationship between high FDI penetration and upgrading of intra-industry trade pattern holds in some cases - as for road vehicles export in all three countries and telecommunication in Hungary. On the other hand, the intraindustry trade pattern did not improve in intensively exporting industries with low FDI penetration (as machinery in the Czech Republic, iron and steel in the Czech Republic and Poland). In some other cases (machinery in Hungary, clothing and paper and paperboard in Poland), medium FDI penetration did not bring about a sizeable amelioration in the quality of trade ${ }^{3}$.

Following several years of buoyant growth, the highly open and strongly integrated Czech economy, was hit by the global crisis, with the dramatic collapse in trade playing a major role. This has translated into a deep recession of the manufacturing sector. The automotive industry, which accounts for around $16 \%$ of Czech total exports, was particularly affected. The slump in economic activity of $4.2 \%$ of GDP in 2009 forced labour market adjustments (European Commission, Occasional papers 65, 2010). The economy started to recover from the recession in the third quarter of 2009 supported by the stimulus measures implemented internally and abroad. Due to the temporary nature of a number of measures implemented in Europe (for instance car scrapping schemes), the recovery path will largely depend on sustained growth in foreign demand. The Czech Republic should be moving towards high-tech production and more developed services sector. The framework conditions for innovation could be strengthened in order to encourage R\&D-intensive investment and increase the high-tech content of production and exports.

So, the observed results prove that FDI inflow has been a necessary, but not a sufficient condition for speeding-up and upgrading export. Non-export-generating FDI was mostly driven by internal market factors, initially frequent in bigger countries. Other FDI inflows, aiming at cheap labour exploitation, could increase export, but usually low quality export goods. The best opportunities of enhancing export quality were provided by investment of multinationals aiming at rationalising their networks for other motives than cheap labour (e.g. qualifications, existing technologies). Such investments were the most frequent in Hungary enjoying a stable privatisation and durability of FDI-attracting incentives and offering qualified and disciplined labour that all the more accepts modest wages (Lissowska, 2002).

For instance, in Estonia, GDP growth after mid 2000s was favourable, especially due to favourable developments in the service sector and export growth. Export growth improved economic conditions in Estonia during the last decade, most likely due to strong productivity growth and increasingly diversified export/import structures that reduced vulnerability in terms of trade deterioration. In the overproduction period, competitiveness was eroded as wage growth outpaced productivity growth; however, current ongoing adjustment in costs is benefiting the competitiveness of the tradables sector. Ensuring more productive investment, in particular in export-oriented industries, could raise productivity and support the trend growth while sustaining competitiveness.

\footnotetext{
${ }^{3}$ Source: External and intra-European Union trade, data 2004-2009, 2010 edition, Eurostat, European Commission, website http://ec.europa.eu/eurostat
} 
Starting from 2000, another Baltic country, Latvia experienced rapid growth in investments, which encouraged the modernization of production and the introduction of new technologies. In Latvia, the investment to GDP ratio has risen to maintain strong economic growth while a healthy banking sector has helped allocate savings towards the most productive investments. In the boom years the tradable sector was largely neglected, losing much of its competitiveness. For Latvia to be able to gain new export markets and produce more innovative products, productivity and skill levels need to be raised significantly.

Additionally, in Lithuania, economic growth has been stimulated since 2001 by the expanding internal market after EU accession with favourable export conditions and rising household incomes bringing economic growth to the general population (Festic M., Kavkler A. and Repina S., 2011).

The economy of Romania grew strongly in the context of strong household spending, accelerating investment growth and FDI. The credit-led domestic demand growth was accompanied by sizeable productivity increases and moderate wage growth until 2003, as well as cuts in social security contributions, which contributed to the external competitiveness of Romania. The country is a regional leader in multiple fields, such as IT and motor vehicle production. The main Romanian exports include agricultural products, chemicals, footwear, fuels, machinery, metal products and textiles.

Surely the EU countries were heavily affected by the global financial downturn and the gross domestic products were contracted. For example, until 2009, Romanian economic growth was among the fastest in Europe (officially 8.4\% in 2008 and more than three times the EU average) and the gross domestic product of the country was contracted by $7.2 \%$ in 2009 and $1.2 \%$ in 2010. In 2011 industrial production was also strong, responding to external demand, but has recently come down somewhat on account of the slowdown in export markets. After the almost entirely export-led growth in 2011, growth is expected to become more broad-based in 2012 as the initial strong increase in exports spills over into domestic demand. External demand is expected to remain supportive, but to be less robust in 2012 due to the worsening economic outlook in Europe and other parts of the world.

Indeed, in 2000s the progress in the implementation of reforms has been an important driver for Bulgaria in achieving macroeconomic stability and productivity improvements. The consumption spending was important, stimulated by easier access to credit, lower taxes and lowering unemployment, in conjunction with accelerating investments.

Before the transition period, the industries of Bulgaria were mainly agriculturefocussed and everything was state-run. At present, Bulgaria has recovered remarkably from that unstable and weak economy in 1990's. The country has begun privatizing the agricultural sector and it is also developing rapidly in the industrial areas. Since the country has a privately owned agrarian economy in most of its regions, the mass production of commercial crops is extensive. It thus exports large quantities of this produce every year. The mining industry is very important in Bulgaria. It is one of the main sectors that drive the entire economy. As always, efficient mining requires not only skill but also highly specialized machinery. Bulgaria does not produce these machines and, therefore, they need to be imported. During the last decade its main industrial exports to the EU were textiles and clothing, iron and steel. Bulgaria's main agricultural exports to the EU were 
cereals; oil seeds oleaginous fruits and meat ${ }^{4}$. The Bulgarian economy's relatively high degree of specialization in low-to-medium technological goods (such as metals, chemical products, clothes and textiles), which experience strong international competition, makes Bulgarian exports particularly sensitive to price-induced changes in external demand. Bulgaria entered a recession in the first quarter of 2009. Over a longer horizon, the further rebalancing of the external accounts and the sustainability of the improvements could largely depend on the economy's price and cost competitiveness and its ability to shift from the non-tradable towards the tradable sector.

\section{Export development and other factors affecting the economic development of Armenia}

Formerly, Armenia was traditionally considered an exporter country, but the exports were directed mainly to Soviet Union markets and, for this reason, the character of export development was significantly different from other exporter countries with market economy. Armenia was one of the most industrialized economies of the former Soviet Union (FSU) with energy, metallurgy, machine-building and the chemical industry as leading producers. Armenia's main export strengths laid in the manufacturing sector, the share of which in the country's export was close to 95\%. Light industry commodities were the most traded items $(37.7 \%)$, followed by machinery $(25.2 \%)$, food $(14.3 \%)$ and chemicals $(10 \%)$. In fact, the pre-transition structure of Armenia's economy, especially industry, proved to be quite vulnerable to external shocks (Avanesyan and Freinkman, 2003). This was primarily due to the role played by big industrial plants that produced mostly intermediary goods, with both suppliers and customers located in the rest of the former Soviet Union (FSU).

A high dependence on export of parts, components, and tools (especially for defence use) to other FSU states, which accounted for about 40 percent of total industrial export, as well as on imports of raw materials, played a critical role in the steep decline of industrial output in the early '90s in Armenia (Freinkman, Polyakov and Revenco, 2004).

Hence, traditional Armenian export volumes could not be sustained at the Soviet levels after the disintegration of the FSU because of a number of factors:

- a sharp decline in defence and other final demand in Russia and other FSU states, political factors that pushed Russian producers (e.g., in defence industries) to switch to local suppliers;

- the low competitiveness of Armenian goods, especially in the consumer sector, after energy and other subsidies had been withdrawn: FSU markets were mostly lost to competitors from lower-cost countries, e.g., Turkey and China;

- $\quad$ new cost factors, such as increased transportation costs for Armenian goods.

In short, since the deep downturn of 1991-1993 and up to 2008 the economy of Armenia entered the phase of continuous and rapid economic growth. Starting from mid-2000, Armenia's export volume also increased till the 2009 crisis. However, export

${ }^{4}$ Source: External and intra-European Union trade, data 2004-2009, 2010 edition, Eurostat, European Commission, website http://ec.europa.eu/eurostat 
concentration by the products started to reduce since 2008, due to export growth of some new products (Vardanyan and Avagyan, 2008).

Specifically, several factors contributed to this improvement:

- improvements in the business environment that included reductions in the administrative burden on the private sector, improved communication between the government and the private sector, and enhanced government capacity to promote investment and exports;

- $\quad$ improved relations with the Diaspora, which increased somewhat the inflow of Diaspora investments; and

- $\quad$ increased remittances, which to a large extent reflect an improved performance of the Russian economy since the 1998 crisis (Freinkman, Polyakov and Revenco, 2004).

Nevertheless, even though it has a very liberal trade regime, Armenia is not sufficiently integrated into international production networks. Because of the blockade of borders with Azerbaijan and Turkey, high transport costs hinder Armenia's participation since bringing semi-processed materials for further processing or manufactured parts and components for assembly, as it is the case in many Central European countries, is not economically viable.

Basically, Armenia's exports are excessively concentrated in a few product categories: precious stones and metals (jewellery and diamond polishing), mining products (copper and molybdenum), metals and products thereof, and food processing (food, agricultural product, alcoholic and non-alcoholic beverages, tobacco and row materials). In the other groups there are a number of exported commodities, in small volumes, however. Since 1999, Armenia started to export some new manufacturing products, such as automotive and machinery parts, spare parts for watches, components of optical instruments, etc. But exports in most of these new categories remain small.

Consequently, since both diamonds and jewellery are transported by air, they are not affected by the blockade, and since they are high value items, the transport costs constitute a small share of their price. The blockade, however, is detrimental to low value large volume items such as clothing, where transport costs constitute a significant share of the price and adversely affects competitiveness. Since raw diamonds are imported and cutting and polishing takes place in Armenia, only a relatively small percentage of the value of exported diamonds is accounted for in exports. For instance, in 2008, the export of jewellery was reduced by $50 \%$ (diamond cut not included).

Definitely, there is a positive link between export diversification and per capita GDP (Funke and Ruhwedel, 2001). Therefore, one of the main objectives of the export development of Armenia has to be diversification, which means developing new products, exporting new products and moving up the value added chain of export products.

Furthermore, the composition of exports of Armenia illustrates the following structural weakness in international integration: there is a gap between Armenia's endowment in skilled labour and its content in Armenia's export offer. The share of unskilled labour intensive products in Armenian exports appears to be below what might be expected from Armenia's endowment as well as from what developments in the factor intensity of exports of other transition economies might indicate. While garments have accounted for a huge share of manufactured exports from European transition economies, this has not been the case with Armenia. High transportation costs favour exports of those products 
with high value relative to weight and discourage sales of the bulky low cost products of light industry, which usually involve unskilled labour-intensive activities. The low share of unskilled labour-intensive products in Armenia's exports while unemployment remains at double-digit levels points to Armenia's inability to tap the opportunities offered by global markets.

For instance, successful European transition economies moved from textiles and clothing, footwear, and furniture to automobiles, heavy machinery and information and communications technology. At the same time Armenia has successfully entered the diamond global value chain but has yet to participate in other value chains and networks, including first-stage simple networks. Textiles and clothing has a comparatively small share in Armenian exports.

Thus, with a stronger export performance and diversification, the growth of the Armenian economy could have been potentially higher and more employment-oriented. While exports have recorded a healthy growth since 1999 until 2009, export growth continues to be concentrated mainly in sectors with limited employment opportunities. The expansion of manufactured exports, especially those associated with global value chains and production and distribution networks would go a long way towards addressing this challenge.

The EU trade relations with Armenia are governed by a Partnership and Cooperation Agreement (in force since July 1999), including measures for:

- $\quad$ non-preferential trade - the parties are forbidden to impose discriminatory tariffs on each other or restrict the quantity of goods traded between them.

- $\quad$ gradual alignment of the partner country's legislation and procedures to the EU's main trade related laws and standards, aiming to further deepen the partner's trade and economic integration with the EU, including a better practical access for its products to EU markets.

The European Neighbourhood Policy (ENP) was developed in 2004, with the objective of avoiding the emergence of new dividing lines between the enlarged EU and neighbours. Armenia benefited from the general arrangement of the EU Generalised System of Preferences (GSP) in 2006-2008, which provided preferential access to the EU market in the form of zero duties on 3300 products and reduced tariffs for other 3900 goods.

In line with the objectives of the European Neighbourhood Policy, the EU aims at establishing a deep and comprehensive free trade area (DCFTA) with Armenia once the necessary conditions for it have been met. As part of the future bilateral Association Agreement, the DCFTA should in particular enhance Armenia's access to the European market and encourage further European investment in Armenia.

In December 2008, Armenia qualified for the special incentive arrangement for sustainable development and good governance (GSP +) under the EU GSP Regulation for 2009-2011. This allows Armenia to export to the EU 7200 products without any customs duties. In order to keep these enhanced preferences during the lifetime of the GSP Regulation Armenia needs to ensure effective implementation of the 27 core international conventions on sustainable development and good governance listed in the Regulation. However, there is still scope for improvement in Armenia's GSP use, in particular regarding diversification of exports. In order to make the best possible use of 
the GSP + preferences and increase and diversify its exports to the EU, Armenia should continue regulatory approximation of its trade related legislation and procedures with the main EU and international trade related laws and standards.

The new EU Eastern Partnership (EaP) launched in May 2009 builds upon the ENP and aims at enhancing the EU relations with the Eastern ENP countries. The EaP has brought in particular a perspective of new enhanced bilateral framework agreements - Association Agreements - between the EU and its Eastern Neighbours, and firmly embedded possible future bilateral deep and comprehensive free trade areas in this framework.

The EU is Armenia's main trading partner, holding a 32.4\% share in Armenia's overall external trade in 2011 (in which exports to Germany - 7.4, Bulgaria 4.6, Italy - 3.2, Netherlands -2.8 , Belgium - 2.5\%). The share of Armenian exports to EU in total exports of the country was $45.7 \%$, and the share of Armenian imports from EU in total imports was $28.2 \%$ in $2011^{5}$. The main EU exports to Armenia are machinery and transport equipment, pearls and precious stones, chemicals, food products and textiles. Armenian exports to the EU consist mainly of base metals and products made of them, as well as pearls and precious stones.

Both data from the EU's statistical office, Eurostat, and Armenia's data for 2009 confirm a sharp decline in the bilateral trade due to the effects of the global financial and economic crisis. According to Eurostat, there has been a $21 \%$ decrease in EU exports and a 56\% drop in EU imports in 2009. In 2010 and 2011 the Armenian export to EU have started to go up slightly.

Despite the overall positive developments, bilateral trade remains very low in volume and is insufficiently diversified, in particular regarding Armenia's exports. Closer trade and economic integration with the European Union can be a key factor for Armenia's economic growth.

In addition, the role of higher education is very important to achieve export development - to have highly qualified outward-oriented business managers. This is a main issue for harmonization of production, export structure and export potential of the country with specializations and specialties structure in universities and in colleges in the country (Grigoryan, 2011). In the developed countries of EU there are many research universities as a good example of education-science-business cooperation, and this kind of activity of universities needs to be developed in EU developing countries as well as in Armenia.

\section{Conclusions}

As a result, exports have a positive impact on national prosperity and contribute to the development of national industries, to improved productivity, and to the creation of employment in the EU member countries and in Armenia as well. At the same time, each country has its own distinctive features in export development, which affects economic development differently.

\footnotetext{
${ }^{5}$ Source: "Socio-Economic Situation of Republic of Armenia, January-December 2011", statistical handbook (in Armenian), National Statistical Service of RA, 2012, pages 117-122
} 
Of course, the single market of $\mathrm{EU}$ is the biggest and most available market for national exporters in EU, but, the construction of the internal market in Europe does not seem to have altered the competitive positions of the states in the internal EU market. Similarly, EU membership was expected to allow further economic expansion due to the fact that consumption and investment in the new member states (NMS) came to the forefront of economic expansion after 2003. Before the last global economic crisis, progress in the implementation of reforms has been an important driver for the NMSs in achieving macroeconomic stability and productivity improvements, although Central and Eastern European countries (CEECs) will have to find their place in the European Union confronted to the globalisation challenge.

Small open economies that concentrate on few closely related trade partners tend to be more exposed to external demand shock risks than countries with a variety of export destinations or less trade openness. Similar arguments refer to the concentration in the sectoral composition of exports. In addition, technology-intensive products and services are found to be much less sensitive to changes in relative costs than low-technology sectors.

At the same time, Armenia's exports are still highly concentrated. The absolute majority of export from Armenia is ensured by four main commodity groups: precious stones, minerals, base metals and food. During the last decade these product groups accounted for approximately 3/4 of Armenia's total exports. Therefore, the process of development of Armenia involves moving from simple poor-country goods to more complex rich-country goods. This process is often called structural transformation. Structural transformation depends on the fact whether companies in Armenia can move their production towards products with higher sophistication. It is unlikely for producers in Armenia to develop comparative advantage in goods with higher implicit income levels, without extra supportive measures and involvement of the government. Proper diversification policies should help Armenian companies make an easier jump towards more sophisticated products, taking into account the current position of Armenia in the world product market and also the experience of EU member countries. 


\section{References:}

- $\quad$ Almeida Couto João Pedro, Maria Teresa Borges Tiago, José Cabral Vieira, and Mário Amaral Fortuna, Contextual and Operational Determinants of Export Performance of Companies in Europe, The Business Review, Cambridge, Vol. 5, Number 1, Summer 2006

- Amiti M., New trade theories and industrial location in the EU: a survey of evidence, Oxford Review of Economic Policy, (1998), Volume 14, Issue 2, pages 45-53.

- $\quad$ Avanesyan Vahram and Lev Freinkman. (2003). Costing-out the Big Bang: Impact of External Shocks on the Armenian Economy at the Outset of Transition. Armenian Journal of Public Policy 1:1:1-34.

- $\quad$ Barrell, R., Pain, N., (1997). Foreign direct investment, technological change and economic growth within Europe. Economic Journal 107, 1770-1786.

- Barrell, R., Pain, N., (1998). Real exchange rates, agglomerations and irreversibilities: Macroeconomic policy and FDI in EMU. Oxford Review of Economic Policy 14 (3).

- Barrell Ray, and Nigel Pain, (1999). Domestic institutions, agglomerations and foreign direct investment in Europe, European Economic Review 43 (1999) 925Đ934, National Institute of Economic and Social Research, Smith Square, 2 Dean Trench Street, London SW1P 3HE, UK

- $\quad$ Berger, H. and V. Nitsch (2010): "The Euro's Effect on Trade Imbalances", IMF Working Paper 10/226.

- $\quad$ Biroli, P., G. Mourre and A. Turrini (2010): "Adjustment in the Euro Area and Regulation of Product and Labour Markets: An Empirical Assessment", CEPR Discussion Paper 8010.

- Carlin, W., Glyn, A., and J. van Reenen, 2001, "Export Performance of OECD Countries: An empirical Examination of the Role of Cost Competitiveness", The Economic Journal 111, pp. $128-162$.

- Cuerpo Carlos, Hobza Alexander, Mordonu Aurora, Sissoko Adja, Tucci Alessandra, Zeugner, (2012). Scoreboard for the surveillance of macroeconomic imbalances, European Economy, Occasional paper 92, February 2012, European Commission, European Union

- $\quad$ European Economy 7, 2009, Economic Crisis in Europe: Causes, Consequences and Responses, European Commission, 1-108

- $\quad$ European Economy, 2010, Macro structural bottlenecks to growth in EU Member States, Occasional paper 65, European Commission, European Union, July 2010, 1-131

- External and intra-European Union trade, data 2004-2009, 2010 edition, Eurostat, European Commission, website http://ec.europa.eu/eurostat

- Festic M., Kavkler A. and Repina S., (2011), The macroeconomic sources of systemic risk in the banking sectors of five new EU member states, Journal of Banking \& Finance 35 (2011) 310-322

- Fontagné, Lionel, Freudenberg, Michael and Péridy, Nicolas (1997), "Trade Patterns inside the Single Market", CEPII, document de travail n 97-07. 
- Freinkman Lev, Evgeny Polyakov, Carolina Revenco, (2004), Armenia's Trade Performance in 1995-2002 and the Effect of Closed Borders: A Cross-Country Perspective, Working Paper No. 04/04, World Bank, January 2004

- $\quad$ Frias, Isidro, Iglesias, Ana, Neira Isabel (1999), Regional specialization and trade patterns in Europe. Working Paper Series Economic Development. No 46, University of Santiago de Compostela. Faculty of Economics. Pages 18-19

- Funke Michael and Ralf Ruhwedel, (2001), Product Variety and Economic Growth: Empirical Evidence for the OECD Countries, IMF Staff Papers, Vol. 48, No. 2, 2001, 225-242

- Girma, S., Greenaway, D., and Kneller, R. (2004) Does Exporting Increase Productivity? A Microeconometric Analysis of Matched Firms. Review of International Economics, 12(5), 855-866.

- Greenaway, David, Hine, Robert and Milner, Chris (1994), "Country-Specific Factors and the Pattern of Horizontal and Vertical Intra-Industry Trade in the UK", Weltwirtschaftliches Archiv, Band 130, pp 77-100.

- Grigoryan Karen (2011), The key issues of the improvement of export promotion policy at the macro- and micro levels, International scientific conference on "Project management", proceedings book, volume 2, Triavna, Bulgaria, pp 70-75

- Grigoryan Karen (2006), "The basic features of export promotion policy in developing countries", paper, Armenian trends, Q2, 2006, AEPLAC, USAID, pp 41-47.

- Hausmann R., Rodrik D. and A. Velasco, (2005), Growth diagnostics, John F. Kennedy School of Government, Harvard University

- Hunya, G., (2001). Uneven competitiveness of industries in the wake of foreign penetration of advanced economies in transition. Transnat. Corp. 10 (2), 35-66.

- Jansen Marion, International trade and the position of European low-skilled labour, World Trade Organization, Economic Research and Analysis Division, Staff Working Paper ERAD-2000-01, November 2000

- Jansen, Marion and Landesmann, Michael (1999): “European Competitiveness: Quality rather than Price" in Fagerberg, Guerrieri and Verspagen (eds.): The Economic Challenge for Europe. Edward Elgar; pp 46-83.

- Krugman Paul, What's new about the new economic geography? Oxford Review of Economic Policy, (1998) 14(2): pages 7-17

- Mkrtchyan Tatul (2007). Globalization under the conditions of open economy, Proceeding book of scientific works on Information Technologies and Management, December 2007, pages 149-155

- $\quad$ Lages, L.F., Montgomery, D.B., (2004), “Export performance as an antecedent of export commitment and marketing strategy adaptation: evidence from small and mediumsized exporters", European Journal of Marketing, Vol. 38, Nos. 9/10, pp. 1186-1195.

- Lissowska Maria, East European prospective members of the European Union under globalisation pressure, Warsaw School of Economics, Al. Niepodległo'si 162, 02554 Warsaw, Poland, Economic Systems 26 (2002) 395-399

- Organisation for Economic Co-operation and Development (OECD), Statistics portal, http://stats.oecd.org/index.aspx 
- Ottaviano Gianmarco I. P. (2011), “'New' new economic geography: firm heterogeneity and agglomeration economies" Journal of Economic Geography 11 (2011) pp. 231-240

- Ottaviano, G., Puga, D., (1997). Agglomeration in the global economy: A survey of the New Economic Geography. Discussion paper no. 356. Centre for Economic Performance, London.

- "Socio-Economic Situation of Republic of Armenia, January-December 2011", statistical handbook, in Armenian, National Statistical Service of RA, 2012, pages 117122

- $\quad$ Stefan Czarny, E., Lang, G., (2002). Poland's accession to EU. Some lessons from the international trade theory. Bank i Kredyt 2, 20-30.

- Vardanyan Knarik, Avagyan Gayane, (2008). Economic development and two points of view of exchange rate policy, inter-university conference's proceedings book, Yerevan, "Tntesaget" publ., 2008, pages 36-41

- Venables, A.J., (1996). Equilibrium locations of vertically linked industries. International Economic Review 37, 341-359.

- Zemanek, H., A. Belke and G. Schnabl (2010): "Current Account Balances and Structural Adjustment in the Euro Area", International Economics and Economic Policy 7, 83-127. 